\title{
Leandro Herrero, (2008). Viral change: The alternative to slow, painful and unsuccessful management of change in organisations $\left(2^{\text {nd }}\right.$ ed.)
}

\author{
Beaconsfield, UK: Meetingminds. ISBN: 978-1-905776-05-5
}

\author{
RODNEY GRAY
}

Employee Communication \& Surveys, Sydney

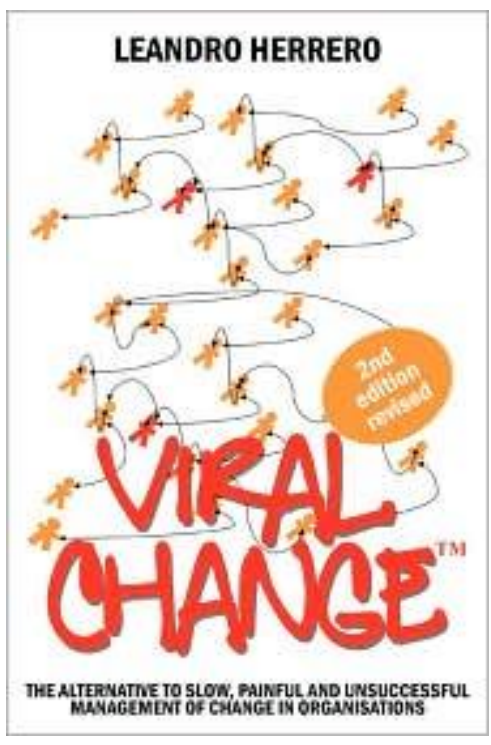

This is a fantastic, easy-to-read paperback (written by a psychiatrist turned organisational consultant) that would appeal to almost anyone interested in organisational change. It is almost in the 'I couldn't put it down' category.

Like many HR practitioners, I have long wondered about the best way to manage organisational change. None of the traditional processes work well. I had been impressed by Malcolm Gladwell's The Tipping Point - how little things can make a big difference (Abacus, 2000) about social change and how changed behaviour can suddenly become the norm. Viral Change marries Gladwell's tipping point concepts (especially 'The Law of the Few') to viral communication (as espoused by T.J. Larkin - see Communicating Big Change Using Small Communication at www.larkin.biz).

Viral Change is also reminiscent of Roses and Rust: Redefining the essence of leadership in a new age by Australians David Clancy and Robert Webber (Business \& Professional Publishing, 1995). They argued that organisations were like gardens; they need to be tended and are not Meccano sets that can be assembled and dissembled at will. Herrero says the structural "plumbing" approach does not work in the highly networked social environments of today. In contrast to the traditional "big issues, big initiatives, big sets of actions + all management levels + massive communication and training = change (initiative)", Herrero recommends Viral Change. This involves using "small sets of behaviours + small number of people + internal networks of influence $=$ fast sustainable change". Using this approach, effective change can even be achieved without all the top executives on board.

The book begins with 15 "change management assumptions", which are progressively more or less debunked. These include "big change requires big actions; only change at the top can ensure change within the organisation; and people are resistant to change". A key concept concerns the changing of everyday behaviour rather than the cultural change that is advocated in traditional approaches. Small changes in behaviour will change the culture. 
There are 15 chapters over 387 pages. The main arguments are presented in four sections: language, frames and conversations; new behaviours; tipping points; and rules and rituals ("cultures"). There are countless lists and many diagrams and flowcharts. The result is a "how to do it" approach that is both radical and workable.

It is possible to gain a feel for what the book is about by going to www.viralchange.net. The site contains various materials, including presentations. It also offers the book for about half the bookshop price in Australia.

Viral Change is self-published. Despite being a second edition it needs a professional edit and justifies printing using proportional spacing. Nevertheless, it is strongly recommended for experienced practitioners who wish to understand how to best manage change in organisations. I suggest that you do not attempt a change program without having had a careful read of this book first. It will cause you to think hard, but you will enjoy doing it. 